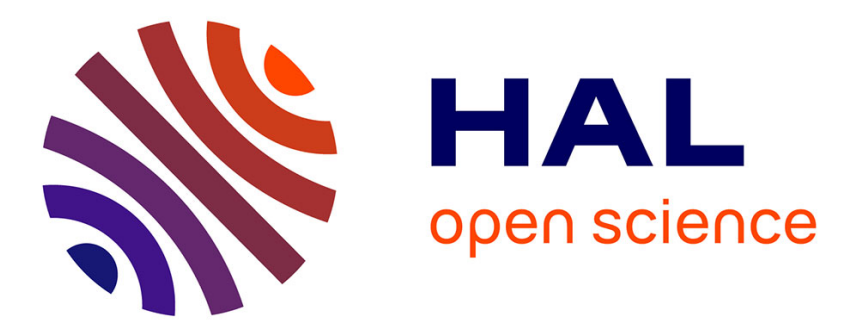

\title{
Bacterial degradation of large particles in the southern Indian Ocean using in vitro incubation experiments
}

Christos Panagiotopoulos, Richard Sempere, I Obernosterer, L Striby, Madeleine Goutx, France van Wambeke, S Gautier, R Lafont

\section{- To cite this version:}

Christos Panagiotopoulos, Richard Sempere, I Obernosterer, L Striby, Madeleine Goutx, et al.. Bacterial degradation of large particles in the southern Indian Ocean using in vitro incubation experiments. Organic Geochemistry, 2002, 33 (8), pp.985-1000. 10.1016/S0146-6380(02)00057-8 . hal-00812107

\section{HAL Id: hal-00812107 https://hal.science/hal-00812107}

Submitted on 28 Nov 2020

HAL is a multi-disciplinary open access archive for the deposit and dissemination of scientific research documents, whether they are published or not. The documents may come from teaching and research institutions in France or abroad, or from public or private research centers.
L'archive ouverte pluridisciplinaire HAL, est destinée au dépôt et à la diffusion de documents scientifiques de niveau recherche, publiés ou non, émanant des établissements d'enseignement et de recherche français ou étrangers, des laboratoires publics ou privés. 


\title{
Bacterial degradation of large particles in the southern Indian Ocean using in vitro incubation experiments
}

\author{
Christos Panagiotopoulos ${ }^{\mathrm{a}}$, Richard Sempéréa,*, Ingrid Obernosterer ${ }^{\mathrm{b}, 1}$, \\ Laurent Striby ${ }^{\mathrm{a}}$, Madeleine Goutx ${ }^{\mathrm{a}}$, France Van Wambeke ${ }^{\mathrm{a}}$, \\ Sophie Gautier ${ }^{\mathrm{a}}$, Raymond Lafont ${ }^{\mathrm{a}}$ \\ ${ }^{a}$ Laboratoire de Microbiologie Marine, CNRS/INSU, UMR 6117, Centre d'Océanologie de Marseille, Université de la Méditerranée, \\ Campus de Luminy, Case 907, F-13 288 Marseille Cedex 9, France \\ ${ }^{\mathrm{b}}$ Department of Biological Oceanography, Institute for Sea Research (NIOZ), PO BOX 59, 1790 AB Den Burg, \\ Texel, The Netherlands
}

\begin{abstract}
Large particles $(>60 \mu \mathrm{m})$ were collected at 30 and $200 \mathrm{~m}$ water depth by in situ pumps in the southern Indian Ocean in January-February 1999. The samples were incubated under laboratory conditions with their own bacterial assemblages for 7-17 days in batches under oxic conditions in the dark. Particulate and dissolved fractions of organic carbon, amino acids, sugars and lipids, as well as bacterial production were quantified over time. During the experiments, $32-38 \%$ and $43-50 \%$ of total organic carbon (TOC) was mineralized and considered as labile material in the Polar Front Zone (PFZ) and Sub-Antarctic region (SAr), respectively. This material was utilized with a bacterial growth efficiency (BGE) of 10-21\% (PFZ) and 12-17\% (SAr), with the lower values being observed for surface samples (30 $\mathrm{m})$. These results imply that most (79-90\%) of the incorporated carbon from large particles was respired as $\mathrm{CO}_{2}$. The study revealed that the initial relative abundance of the three main classes of organic matter, including sugars, amino acids and lipids, varied greatly between SAr and PFZ, with sugars being more abundant in SAr (15-19\% of TOC) than in PFZ (8-9\% of TOC). In the PFZ, mineralization rates of amino acids and lipids were two to ten fold higher than those of sugars, whereas the opposite was observed in SAr biodegradation experiments. Moreover, our results suggested that organic carbon is mineralized by bacteria more rapidly in the euphotic zone of the SAr than the PFZ. The differences observed between the two sites may be related to the more rapid dissolution of silica as well as the higher temperatures and bacterial production encountered in SAr waters. The bacterial processes apparently affect the composition of material sinking to the ocean interior. (C) 2002 Elsevier Science Ltd. All rights reserved.
\end{abstract}

\section{Introduction}

Large $(>60 \mu \mathrm{m})$ non-living sinking particles are mainly produced in the upper layers of the ocean (euphotic zone) and consist of biogenic material such as faecal pellets, marine snow, algal and bacterial exudates or exopolymer particles that sink to the sea floor with different rates (Fowler and Knauer, 1986; Alldredge and Silver, 1988; Turley and Lochte 1990; Asper et al., 1992; Alldredge et al., 1993). Such material is an active component of the exchange of particulate (Martin et al., 1987) and dissolved (Alldredge, 2000) organic material between surface and deep waters of the ocean. During transit in the water column, hydrolytic activity on aggregates by attached bacteria gives rise to dissolved organic carbon (DOC) release, which is taken up mainly by free-living bacteria that in turn produce $\mathrm{CO}_{2}$ through 
respiration (Cho and Azam, 1988; Herndl, 1988; Karner and Herndl, 1992, Smith et al., 1992; Hoppe et al., 1993; Sempéré et al., 2000). These processes are relevant to the global carbon cycle since they determine how much of organic and inorganic carbon is sequestered in the ocean interior (Siegenthaler and Sarmiento, 1993).

The organic composition of sinking particles has been described mainly for sediment trap material, focusing on carbohydrates (Ittekkot et al., 1984; Tanoue and Handa 1987; Hernes et al., 1996), amino acids (Lee and Cronin 1982; Wakeham et al., 1984; Lee et al., 2000) and lipids (Wakeham et al., 1984, 1997a; Cailliau et al., 1999; Goutx et al., 2000; Kiriakoulakis et al., 2001), or by using solid state ${ }^{13} \mathrm{C}-\mathrm{NMR}$ spectroscopy (Hedges et al., 2000). Recent studies indicated that bacterial degradation of large marine particles in the water column can be described by a multi-G model (Sempéré et al., 2000), which was initially proposed for sedimentary organic matter (Berner, 1980; Westrich and Berner, 1984; Rabouille et al., 1998). Related studies also demonstrated that particulate organic matter from phytoplankton debris, zooplankton, and axenic cultures of phytoplankton (Henrich and Doyle, 1986; Harvey et al., 1995; Nguyen and Harvey, 1997) follows first order kinetics and does not degrade as a single pool. However, very few data are available on the turnover rates of large particles $(>60 \mu \mathrm{m})$ as well as the amount of organic material released through these processes in the form of dissolved organic matter.

Therefore, particulate organic material (POM) was collected by using in situ pumps from two localities (Polar Front Zone: PFZ and Sub-antarctic region: SAr) in the southern Indian Ocean. The southern Indian Ocean in particular may play a major role in global environmental changes, since it is considered as an important sink for atmospheric $\mathrm{CO}_{2}$ (Metzl et al., 1999), however, very few data are available on the degradation of large organic particles that often dominate the recycling of organic matter. Moreover, this region is characterized as the largest "high nutrient low chlorophyll" region, which exhibits elevated productivity only in the Polar Front due to the entrainment of trace elements (de Baar et al., 1995). In this study the objectives were:

1. to measure the amount and composition of POM, namely organic carbon, sugars, amino acids and lipids, during bacterial degradation of large $(>60 \mu \mathrm{m})$ sinking particles,

2. to better understand particulate-dissolved organic matter transfer during degradation

3. to determine bacterial growth efficiency (BGE) during organic matter degradation,

4. to provide turnover rates for sugars, amino acids and lipids found in the particulate organic material, and
5. to compare data sets between PFZ and SAr for which large differences in particulate material reaching the seafloor have already been reported (Rabouille et al., 1998).

\section{Materials and methods}

\subsection{Study area}

Seawater and particle collection was carried out from January to February 1999 in the southern Indian Ocean in the framework of the Antares-4 (ANTarctic RESearch) project, a French contribution to SOJGOFS. Two stations typical of the Southern Ocean at these latitudes were sampled, the first one is located in the Polar Front Zone (PFZ: $46^{\circ} 01.22^{\prime} \mathrm{S} ; 62^{\circ} 56.70^{\prime} \mathrm{E}$ ) and the other is located in the Sub-Antarctic region (SAr: $44^{\circ} 10.92^{\prime} \mathrm{S}$; $63^{\circ} 23.37^{\prime} \mathrm{E}$ ) (Fig. 1; Table 1). The PFZ is located between the Sub-Antarctic Front (SAF) in the north and the Polar Front (PF) in the south. In the upper $200 \mathrm{~m}$, temperature and salinity at PFZ varied from 5 to $10{ }^{\circ} \mathrm{C}$ and from 33.69 to 33.94 , respectively (Table 1). Water masses in SAr, which is located between the Sub-Tropical Front (STF) in the south and the Agulhas return Front (AF) in the north (Park and Gamberoni, 1997), were much warmer with temperature ranging from 11 to $14{ }^{\circ} \mathrm{C}$ and the corresponding salinity range was $34.35-34.82$ (Table 1). Depth integrated values $(0-150 \mathrm{~m})$ of biogenic silica in PFZ averaged 38 $\mathrm{mmol} \mathrm{m} \mathrm{m}^{-2}$ in the PFZ and $25 \mathrm{mmol} \mathrm{m}^{-2}$ in the SAr, whereas integrated primary production (PP) over 0 $150 \mathrm{~m}$ averaged $28 \mathrm{mmol} \mathrm{C} \mathrm{m}^{-2} \mathrm{day}^{-1}$ in the PFZ and $47 \mathrm{mmol} \mathrm{C} \mathrm{m}^{-2}$ day $^{-1}$ in the SAr (Leblanc et al., in press). Integrated total organic carbon (TOC) values $(0-150 \mathrm{~m})$ averaged $7474 \mathrm{mmol} \mathrm{C} \mathrm{m}{ }^{-2}$ in PFZ and $9642 \mathrm{mmol} \mathrm{C} \mathrm{^{-2 }}$ in the SAr, whereas bacterial production averaged $8 \mathrm{mmol} \mathrm{C} \mathrm{m}^{-2} \mathrm{day}^{-1}$ in the PFZ and $13 \mathrm{mmol} \mathrm{C} \mathrm{m}{ }^{-2} \mathrm{day}^{-1}$ in the SAr (R. Sempéré, unpublished observations).

\subsection{Sampling}

Large particles $(>60 \mu \mathrm{m})$ were collected at 30 and 200 $m$ depth using in situ pumps (Challenger Oceanics) equipped with $60 \mu \mathrm{m}$ pore-size filters (Nitex, Ø: 142 $\mathrm{mm})$. Seawater $\left(\begin{array}{ll}10 & 1\end{array}\right)$ was also sampled at the same depths with Niskin bottles and filtered through $0.2 \mu \mathrm{m}$ pore-size filters (Millipore, Ø: $143 \mathrm{~mm} ; \mathrm{P}<50 \mathrm{~mm} \mathrm{Hg}$ ) in order to remove bacteria and grazers. Prior to filtration, the $0.2 \mu \mathrm{m}$ pore-size filters were flushed with Milli-Q water (2 1) and $0.5-11$ of seawater in order to minimize contamination (Yoro et al., 1999). This water was used for particle extraction from filters and for batch preparation. 


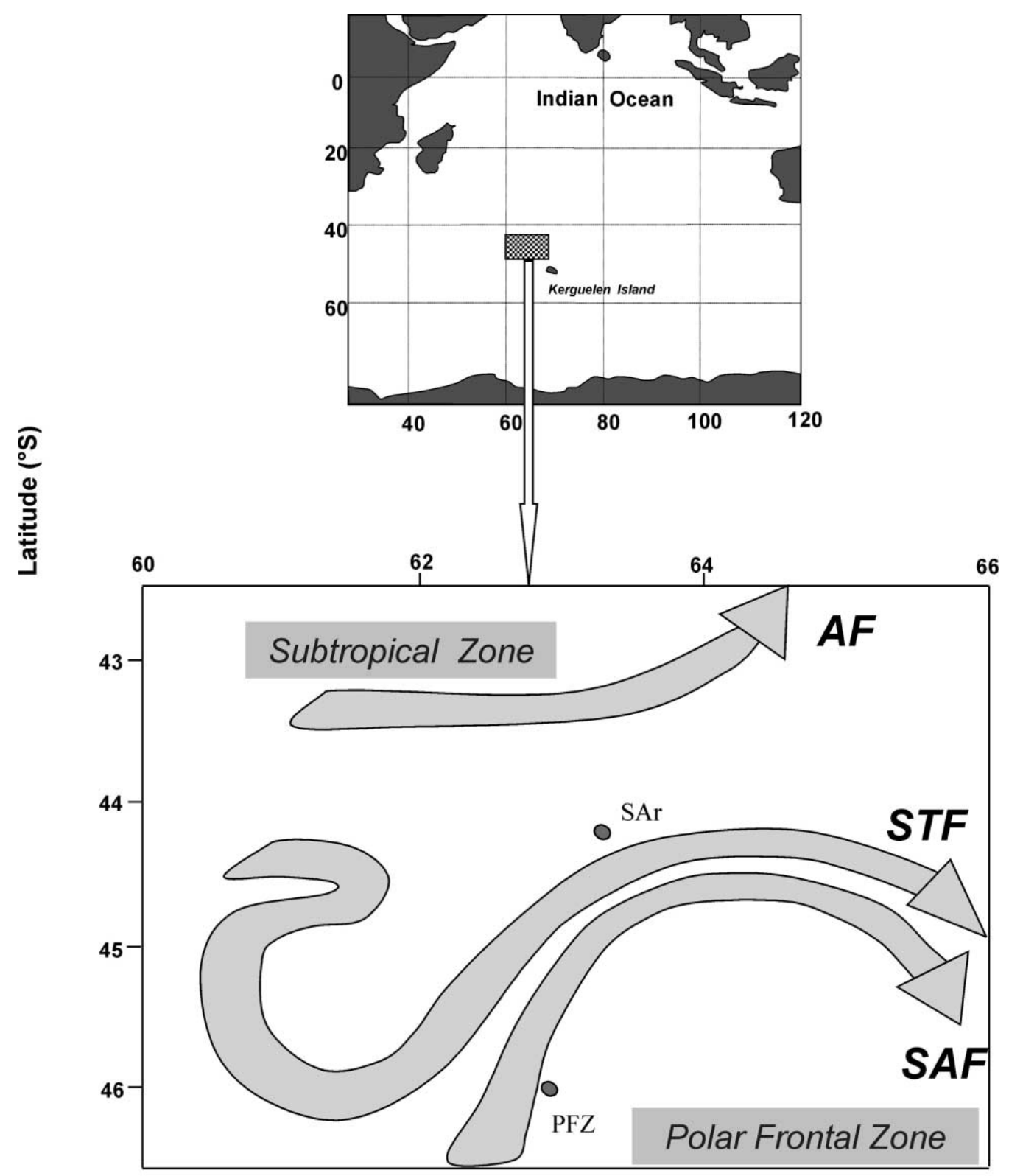

\section{Longitude $\left({ }^{\circ} \mathrm{E}\right)$}

Fig. 1. Locations of stations during the cruise Antares 4 in the Southern Ocean (January-February 1999). Notations: Agulhas Return Front (AF), Sub-tropical front (STF), Sub-antarctic Front (SAF).

\subsection{Incubation experiments}

Within $2 \mathrm{~h}$ of particle collection, swimmers were discarded using squeezers and the filters were placed into Petri dishes. Particles were then extracted from the filters by washing several times with filtered $(0.2 \mu \mathrm{m})$ seawater (total volume $\sim 200 \mathrm{ml}$ ) with a syringe. The mixture was transferred into a 21 polycarbonate bottle filled (previously washed with $2 \% \mathrm{HCl}$ and Milli-Q water) with additional $0.2 \mu \mathrm{m}$-filtered seawater and immediately transferred to incubation bottles $(500 \mathrm{ml}$ glass bottles; combusted $450{ }^{\circ} \mathrm{C}$ ); using a peristaltic pump (Perfifill IQ 2000, Jencons Ltd). The particulate material was incubated on board for 7-17 days (longer incubation times would probably induce anoxic conditions) at in situ seawater temperature $\left(5-14{ }^{\circ} \mathrm{C}\right)$ in the dark and swirled following the protocol of Sempéré et al. (2000) and ArraesMescoff et al. (2001). The headspace-to-sample ratio inside the incubation bottles was about 240:500 $\mathrm{ml}$, which ensured oxic conditions throughout the incubation period.

Sub-sampling of incubations was performed by collecting aliquots for particulate organic carbon (POC), 
Table 1

Summary of particle sampling conditions and in situ seawater characteristics

\begin{tabular}{|c|c|c|c|c|}
\hline \multirow{2}{*}{$\frac{\text { Station }}{\text { Location }}$} & \multicolumn{2}{|c|}{ PFZ } & \multicolumn{2}{|c|}{ SAr } \\
\hline & $46^{\circ} 01.22^{\prime} \mathrm{S}$ & $62^{\circ} 56.70^{\prime} \mathrm{E}$ & $44^{\circ} 10.92^{\prime} \mathrm{S}$ & $63^{\circ} 23.37^{\prime} \mathrm{E}$ \\
\hline Sampling depth (m) & 30 & 200 & 30 & 200 \\
\hline Date of sampling & $18 / 01 / 99$ & $21 / 01 / 99$ & 06/02/99 & $08 / 02 / 99$ \\
\hline Seawater temperature $\left({ }^{\circ} \mathrm{C}\right)^{\mathrm{a}}$ & 9 & 5 & 14 & 12 \\
\hline Salinity & 33.69 & 33.94 & 34.35 & 34.82 \\
\hline POC $(>60 \mu \mathrm{m})(\mathrm{nM})$ & 17.6 & 5.7 & 6.2 & 4.3 \\
\hline In situ TOC $(\mu \mathrm{M})^{\mathrm{b}}$ & 52 & 45 & 75 & 59 \\
\hline In situ BP $\left(\text { ng } \mathrm{C}^{-1} \text { hour }^{-1}\right)^{\mathrm{b}}$ & 44.6 & 3.6 & 153 & 4.4 \\
\hline Flux $\left(\mathrm{mmol} \mathrm{C} \mathrm{m}{ }^{-2} \mathrm{day}^{-1}\right)$ & & 0.57 & & 0.43 \\
\hline Biogenic silica $\left(\mathrm{mmol} \mathrm{m}^{-2}\right)^{\mathrm{c}}$ & \multicolumn{2}{|c|}{38} & \multicolumn{2}{|c|}{25} \\
\hline PP $\left(\mathrm{mmol} \mathrm{C} \mathrm{m}{ }^{-2} \mathrm{day}^{-1}\right)^{\mathrm{c}}$ & \multicolumn{2}{|c|}{28} & \multicolumn{2}{|c|}{47} \\
\hline
\end{tabular}

PFZ: Polar Front Zone; SAr: Sub-Antarctic region. Theoretical sinking fluxes at $200 \mathrm{~m}$ depth for $>60 \mu \mathrm{m}$ particles were calculated according to the formula: $F=v \times C$, where: $F$ : is the calculated flux; $v$ : is the sinking velocity $\left(\mathrm{m} \mathrm{s}^{-1}\right)$; $C$ : is the concentration (nM).

a Seawater temperature at the sampling depth.

b R. Sempéré, unpublished observations.

c Integrated values $(0-150 \mathrm{~m})$ according to Leblanc et al. (in press).

dissolved organic carbon (DOC), particulate and dissolved sugars, amino acids, and lipid analyses as well as for the determination of bacterial production. The peristaltic pump was used to transfer the aliquots $(\sim 50 \mathrm{ml})$ into four glass bottles $(100 \mathrm{ml})$, corresponding to POC, DOC, sugar, amino acid and lipid measurements. The particulate material was collected on $\mathrm{GF} / \mathrm{F}$ filters (nominal retention: $0.7 \mu \mathrm{m}$ ) for further determination of POC, amino acids, sugars and lipids and these were stored in the dark $\left(-17^{\circ} \mathrm{C}\right)$ prior to analysis on shore. The filtrates passing through the $\mathrm{GF} / \mathrm{F}$ filters were transferred into duplicate glass vials, closed with Teflonlined screw caps and stored in the dark $\left(-17{ }^{\circ} \mathrm{C}\right)$ for sugar and amino acid analyses. Samples for DOC were preserved with $\mathrm{HgCl}_{2}$ (final concentration: $10 \mathrm{mg} \mathrm{l}^{-1}$ ) and stored in the dark at $4{ }^{\circ} \mathrm{C}$ (Ogawa and Ogura, 1992). Dissolved lipids were immediately extracted with chloroform from the filtrates (see below) and stored in the dark under $\mathrm{N}_{2}\left(-17^{\circ} \mathrm{C}\right)$. The standard deviation for the particle distribution, which was determined by measuring POC in five replicates, was $5 \%$ at the start of the incubation. Experimental errors based on duplicate analyses were estimated to be about $10 \%$ for the concentration of each chemical parameter and BP during incubation the experiment. Controls $(1$ sub-sample for each sampling depth at 30 and $200 \mathrm{~m}$ ) were prepared by adding $\mathrm{HgCl}_{2}$ (10 $\mathrm{mg} \mathrm{l}^{-1}$ final concentration) to batches containing particles at the start of the experiment and were processed in the same way as above.

\subsection{POC and DOC}

Filters were processed according to Tan and Strain (1979), and assayed on a CS analyzer (CS 125-Leco). In preparation for POC analysis, the $\mathrm{GF} / \mathrm{F}$ filters were covered with a few $\mathrm{ml}$ of $2 \mathrm{~N} \mathrm{H}_{3} \mathrm{PO}_{4}$ and evaporated to dryness at $50{ }^{\circ} \mathrm{C}$ for $12 \mathrm{~h}$ to remove inorganic carbon. The filters were then combusted and the $\mathrm{CO}_{2}$ generated was measured by a non-dispersive infra-red detector, with a standard deviation of $2 \%$. POC values reported in this study were not corrected for bacterial biomass-C (determined from bacterial abundance) since this represented $<5 \%$ of POC.

DOC was measured by high temperature combustion on a Shimadzu TOC 5000 analyzer, as described in Dafner et al. (2001) and Sempéré et al. (2002). A four point-calibration curve was performed daily with standards prepared by diluting a stock solution of potassium hydrogen phthalate in Milli-Q water. The procedural blank ranged from 4 to $8 \mu \mathrm{M} \mathrm{C}$ and was subtracted from the values presented here. TOC concentrations were estimated by summing POC and DOC.

\subsection{Particulate sugars ( $\mathrm{PCHO})$ and dissolved sugars ( $\mathrm{DCHO})$}

Filters were hydrolyzed with $0.1 \mathrm{M} \mathrm{HCl}$ at $100{ }^{\circ} \mathrm{C}$ for $20 \mathrm{~h}$ (Burney and Sieburth, 1977). On cooling, the aqueous acid was evaporated to dryness in a rotary evaporator and the residue was washed with a small volume of water $(200 \mu \mathrm{l})$ which was removed by evaporation. The residue was taken up in $2 \mathrm{ml}$ of Milli-Q water and analyzed for PCHO in order to determine the concentrations and composition of combined sugars. Neutral monosaccharide concentrations in hydrolyzed samples were measured by high performance anion exchange chromatography with pulsed amperometric detection (HPAEC-PAD) according to Mopper et al. (1992) and modified by Panagiotopoulos et al. (2001). Briefly, monosaccharides were separated on an anion 
exchange column (Carbopac PA-1, Dionex) by isocratic elution with $19 \mathrm{mM} \mathrm{NaOH}$ at $17{ }^{\circ} \mathrm{C}$ (column temperature) and detected by an electrochemical detector (Decade, Antec). The detection limit of the method was found to be $25 \mathrm{nM}(\mathrm{S} / \mathrm{N}=3$, loop $20 \mu \mathrm{l})$. Final PCHO concentrations were expressed as $\mathrm{C}$-equivalents.

Since HPAEC-PAD technique provides variable recovery of individual dissolved monosaccharides in seawater because of the desalting steps (Mopper et al., 1992), dissolved monosaccharides were measured by a colorimetric technique with a detection limit of $\sim 500$ nM glucose equivalents (Myklestad et al., 1997). Thus, filtrates were hydrolyzed to give an estimate of DCHO similarly as described above (Burney and Sieburth, 1977) for PCHO and measured on a spectrophometer (Perkin Elmer E201 Lambda). Thus, the concentration of DCHO is equivalent to the sum of free and combined dissolved sugars. Total monosaccharide concentrations (TCHO) were estimated by summing $\mathrm{PCHO}$ and DCHO. DCHO concentrations were converted to C-equivalents by using a molar conversion factor of six. Final TCHO and PCHO concentrations were expressed as $\mathrm{C}$-equivalents.

\subsection{Particulate amino acids (PAA) and dissolved amino acids ( $D A A)$}

Filters were hydrolyzed using $6 \mathrm{~N} \mathrm{HCl}$ at $110^{\circ} \mathrm{C}$ for 20h (Parsons et al., 1984), then the hydrolyzate was neutralized with $6.1 \mathrm{~N} \mathrm{NaOH}$ and the amino acids were measured according to Delmas et al. (1990) using a peristaltic pump (Gilson) and fluorescence labeling with $o$-phtaldialdehyde (OPA). The filtrate was used for the analyses of DAA. The concentration of DAA was determined after hydrolysis $\left(6 \mathrm{~N} \mathrm{HCl}, 110^{\circ} \mathrm{C}, 22 \mathrm{~h}\right)$ and it corresponds to both free and combined dissolved amino acids. Total amino acids (TAA) concentrations were calculated by adding up PAA and DAA (TAA = PAA + DAA). The blanks for the PAA were $0.4-0.5 \mu \mathrm{M}$ ( $\mathrm{cv}=13 \% ; n=3$ for the $0.1-1 \mu \mathrm{M}$ level). The measured concentrations were not corrected for blank values. The detection limit was found at $0.1 \mu \mathrm{M}(0.1-1 \mu \mathrm{M}$ level $)$ which is consistent with Delmas et al. (1990). Final TAA, PAA and DAA concentrations were expressed as C-equivalents by using a molar conversion factor of four, since this value represents an average calculated for the eight most abundant $(78 \%)$ amino acids in marine particles (Lee et al., 2000).

\subsection{Particulate lipids (PL) and dissolved lipids (DL)}

PL were extracted from filters according to Bligh and Dyer (1959). Lipid classes, including glyceride lipids (wax esters, triglycerids, glycolipids and phospholipids) and free lipids (fatty acids, alcohols and sterols) were separated and quantified using a thin layer chromato- graphy-flame ionization detection (TLC-FID) Iatroscan apparatus following the protocol of Striby et al. (1999). Dissolved lipids (DL) were liquid-liquid extracted from the filtrate (4 times with $10 \mathrm{ml}$ of chloroform, last extraction at $\mathrm{pH}<2$ ) in separatory funnels on board and analyzed on land following the same procedure for PL. Total lipids (TL) consisted of the sum of PL and DL $(\mathrm{TL}=\mathrm{PL}+\mathrm{DL})$ and were estimated by adding up the individual classes. The detection limit of the method was found to be 4-5 nmol $(\mathrm{S} / \mathrm{N}=3)$. Final TL, PL and DL concentrations were expressed as $\mathrm{C}$-equivalents by using an average lipid to carbon mass ratio of 0.7 .

\subsection{Bacterial production (BP)}

$\mathrm{BP}$, the rate of increase of heterotrophic bacterial biomass per unit time (ng $\left.\mathrm{C}^{-1} \mathrm{~h}^{-1}\right)$ was estimated from rates of protein synthesis as measured with leucine technique (Kirchman, 1993; Van Wambeke et al., 2001). This technique, widely used in microbial ecology in aquatic waters, is based on the assumption that the rate of protein synthesis is proportional to BP (Kirchman, 1993). At each time point of biodegradation experiment, duplicate samples $(4 \mathrm{ml})$ and a formalin-killed control were incubated with $7.6 \mathrm{nM}-\left[4,5{ }^{3} \mathrm{H}\right]$-leucine (specific activity $136 \mathrm{Ci} \mathrm{mmol}^{-1}$ ) and $200 \mathrm{nM}$ of non-radioactive leucine. Samples were incubated at in situ temperature and in the dark for $3 \mathrm{~h}$, which was in the linear phase of leucine incorporation. Incubations were stopped with formalin ( $2 \%$ final concentration), samples were filtered through $0.2 \mu \mathrm{m}$ cellulose ester filters (GSWP, Millipore) and then extracted with ice-cold 5\% trichloroacetic acid. Samples were counted in a liquid scintillation counter (Packard 1600 TR). Leucine uptake was then converted to $\mathrm{BP}$ based on a conversion factor of $1.5 \mathrm{~kg} \mathrm{C}$ per mol incorporated leucine (Kirchman, 1993).

\subsection{Bacterial growth efficiency ( $B G E$ )}

We determined BGE from TOC decrease and BP increase as follows:

$\mathrm{BGE}=(\mathrm{IBP} / \Delta \mathrm{TOC}) \times 100 \%$

where IBP is the integrated BP over successive time intervals and determined from rates of ${ }^{3} \mathrm{H}$-leucine incorporation, and $\triangle \mathrm{TOC}$ is the amount of TOC utilized during the same time interval. The time interval corresponded to the initial phase of bacterial increase (log phase).

\section{Results}

Water column concentrations of POC of large particles $(<60 \mu \mathrm{m})$ ranged in both stations from 4.33 to 17.6 
$\mathrm{nM}$ (Table 1) and are roughly 3 orders of magnitude lower than those reported for suspended POC $(>0.7 \mu \mathrm{m}$ $\mathrm{GF} / \mathrm{F}$ filters) at the same stations (1.5-17.8 $\mu \mathrm{M}$; Leblanc et al., in press). Assuming a sinking velocity of $100 \mathrm{~m}$ day $^{-1}$ (Wakeham et al., 1984; Alldredge and Silver, 1988), these concentrations roughly correspond to a theoretical organic carbon sinking flux at $200 \mathrm{~m}$ of 0.43 (SAr) and 0.57 (PFZ) mmol $\mathrm{C} \mathrm{m}^{-2} \mathrm{day}^{-1}$ (Table 1). These values are about two orders of magnitude lower than the POC produced from integrated $(0-150 \mathrm{~m})$ primary production $\left(28-47 \mathrm{mmol} \mathrm{C} \mathrm{m}^{-2} \mathrm{day}^{-1}\right.$, Leblanc et al., in press). These flux estimates are likely to be somewhat low because the particles were probably not completely extracted from the in situ pump filters (removal efficiency was estimated to be about $80 \%$ ). Poor estimation of the sinking velocity is also very likely. However, they indicate rapid degradation of organic matter in surface waters, and particularly in SAr judging from the relative ratio POC-flux against PP (POCflux $_{\text {Sar }} \times \mathrm{PP}^{-1}=0.009$; POC-flux $\mathrm{PFZ} \times \mathrm{PP}^{-1}=0.02$ ).

\subsection{Organic carbon concentrations during the experiment}

For all series, initial concentrations of dissolved constituents (DOC and others) in the incubation bottles were systematically higher $(228-488 \mu \mathrm{MC})$ than in the water column $(45-75 \mu \mathrm{MC}$; Table 1) indicating that dissolution and/or bacterial decomposition of POC, started as soon as the particles were washed from the filters and diluted in filtered seawater. This transfer from the particulate to the dissolved phase occurred prior to the commencement of the incubation experiments $(t=0)$ and is consistent with previous studies (Sempéré et al., 2000; Arraes-Mescoff et al., 2001). Hence, TOC concentrations in batches are likely to better represent the decay of POM. During experiment preparation, DOC concentrations in the $0.2 \mu \mathrm{m}$-filtered seawater (see Materials and Methods) were initially slightly higher ( $+5 \mu \mathrm{M} \mathrm{C}$ ) than those determined in discrete samples collected by Niskin bottles (Table 1) at the same station probably because of slight contamination during filtration. This value compared to those released from particulate material $(228-488 \mu \mathrm{M} \mathrm{C})$ at $t=0$ or before the beginning of the experiments may, therefore, be considered to be negligible. This source of contamination probably comes from the organic material that constitutes the filter and it is very difficult to eliminate it completely (Yoro et al., 1999). This trend was not observed for amino acids, sugars and lipids, for which we found similar concentrations as in the water column.

In the PFZ $30 \mathrm{~m}$ and $200 \mathrm{~m}$ biodegradation experiments, TOC concentrations decreased by 32 and $38 \%$ of their initial concentrations, respectively, whereas the corresponding decreases were 43 and $50 \%$ for the SAr biodegradation experiments, suggesting higher lability of $>60 \mu \mathrm{m}$ particles in the SAr (Table 2; Figs. 2 and 3). In control experiments $\left(\mathrm{HgCl}_{2}\right.$-poisoned samples), $\mathrm{BP}$ was not detectable; we observed slight variation of TOC $(\leqslant 10 \%)$ indicating that adsorption of POC and/or DOC on the bottle walls played a minor role in the TOC variations. POC concentrations in PFZ, for both 30 and $200 \mathrm{~m}$ samples decreased by 45 and $21 \%$ of their initial concentrations, respectively. At both depths for SArparticles, POC concentrations decreased by only $\sim 23 \%$ of the initial concentration (Table 2; Figs. 2 and 3). The greatest decrease in TOC and POC concentrations were observed during the first two days (Figs. 2 and 3). Hence there was a sharp decrease of POC concentrations, by $323 \mu \mathrm{M} \mathrm{C}(36 \%$ of initial POC) after 1 day at PFZ-30 $\mathrm{m}, 69 \mu \mathrm{M} \mathrm{C}(19 \%)$ after 1 day at PFZ-200 m, $46 \mu \mathrm{M} \mathrm{C}$ $(10 \%)$ after 2 days at SAr-30 m and $54 \mu \mathrm{M} \mathrm{C}(32 \%)$ after 1 day at SAr-200 m, thereafter concentrations decreased more slowly until the end of the incubation.

Table 2

Bacterial growth efficiencies (BGE\%) calculated from TOC utilization and time-integrated bacterial production calculated for the log phase of the exponential growth and net variations of different pools of organic carbon $(\triangle \mathrm{TOC}, \triangle \mathrm{POC}, \triangle \mathrm{TAA}, \triangle \mathrm{PAA}, \triangle \mathrm{TCHO}$, $\triangle \mathrm{PCHO}, \triangle \mathrm{TL}, \triangle \mathrm{PL}$ ) expressed as percentages of initial amount of organic carbon

\begin{tabular}{|c|c|c|c|c|c|c|c|c|c|c|c|c|}
\hline \multirow[t]{3}{*}{ Sample } & & \multirow[t]{3}{*}{ IP (d) } & \multirow[t]{3}{*}{$P(d)$} & \multirow[t]{3}{*}{ BGE \% } & \multicolumn{8}{|c|}{ Biochemical fraction } \\
\hline & & & & & \multicolumn{2}{|l|}{$\mathrm{OC}$} & \multicolumn{2}{|l|}{ AA } & \multicolumn{2}{|l|}{$\mathrm{CHO}$} & \multicolumn{2}{|c|}{ Lipids } \\
\hline & & & & & TOC & POC & TAA & PAA & $\mathrm{TCHO}$ & $\mathrm{PCHO}$ & $\mathrm{TL}$ & PL \\
\hline \multirow[t]{2}{*}{ PFZ } & $30 \mathrm{~m}$ & 13 & 2 & 10 & -32 & -45 & -61 & -95 & -18 & -21 & -63 & -64 \\
\hline & $200 \mathrm{~m}$ & 17 & 1.13 & 21 & -38 & -21 & -54 & -65 & -15 & -30 & -64 & -58 \\
\hline \multirow[t]{2}{*}{ Sar } & $30 \mathrm{~m}$ & 7 & 1.7 & 12 & -43 & -24 & -30 & -88 & -50 & -54 & -14 & -42 \\
\hline & $200 \mathrm{~m}$ & 14 & 2.11 & 17 & -50 & -22 & -29 & -95 & -37 & -34 & -30 & -71 \\
\hline
\end{tabular}

IP: is the incubation period in days. P: period (days) considered for BGE estimate. $\Delta \%$ was calculated according to the formula: $\Delta \%=100 \times($ final concentration - initial concentration $) /$ initial concentration. 


\section{PFZ}

$30 \mathrm{~m}$

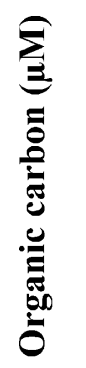
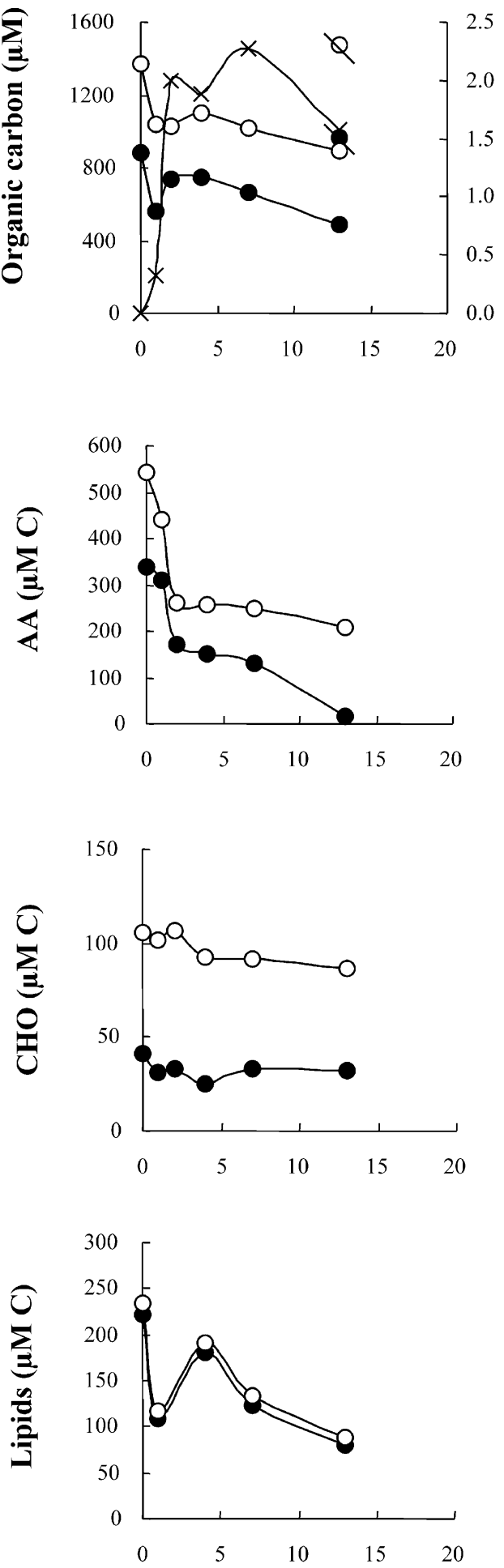

$200 \mathrm{~m}$
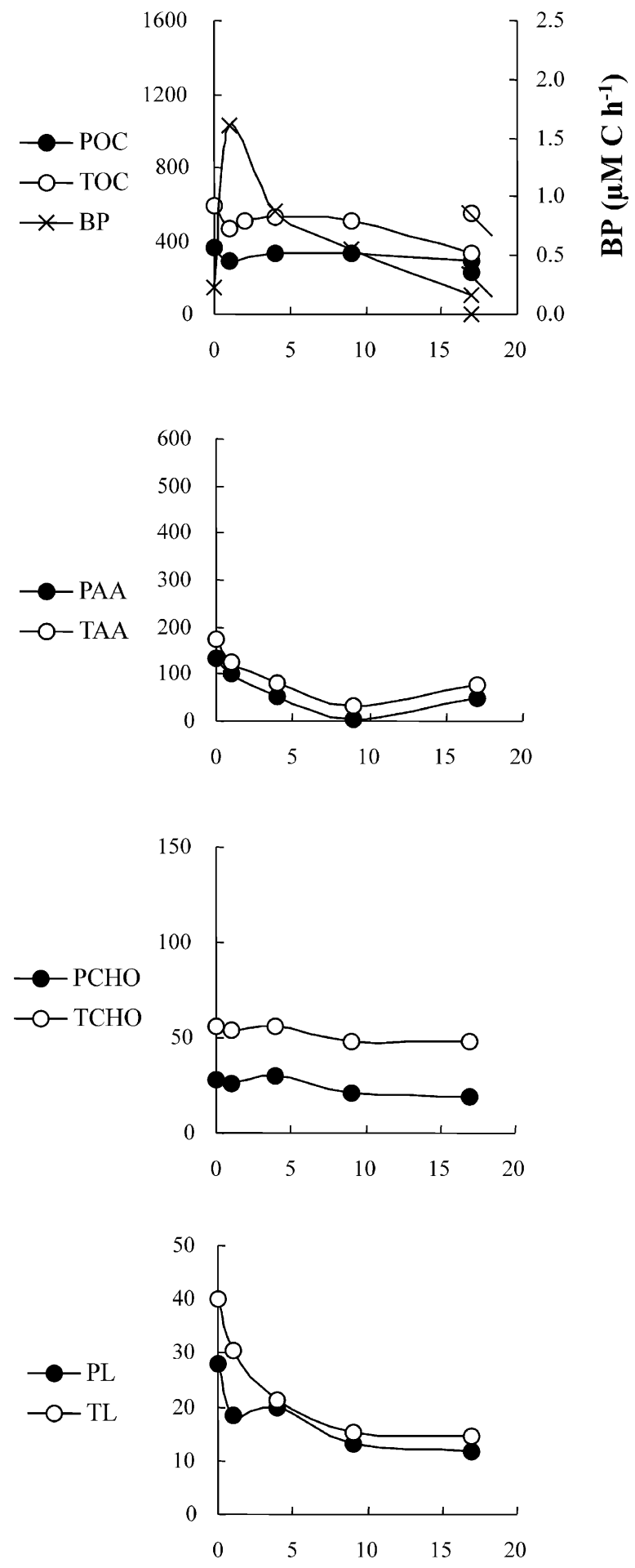

Time (days)

Fig. 2. Time course responses of particulate and total fractions of organic carbon, amino acids, sugars and lipids in relation to bacterial production during biodegradation experiments at PFZ $30 \mathrm{~m}$ and $200 \mathrm{~m}$ depth. Dots with slash represent control experiments for POC and TOC. 


\section{SAr}

$30 \mathrm{~m}$
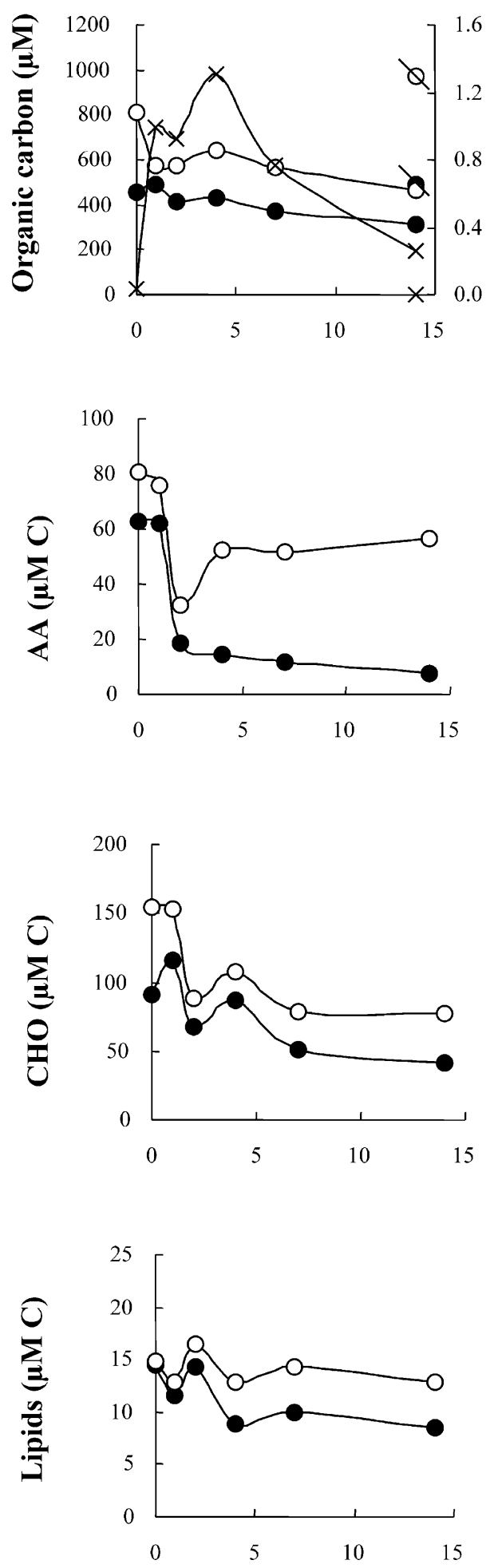

$200 \mathrm{~m}$
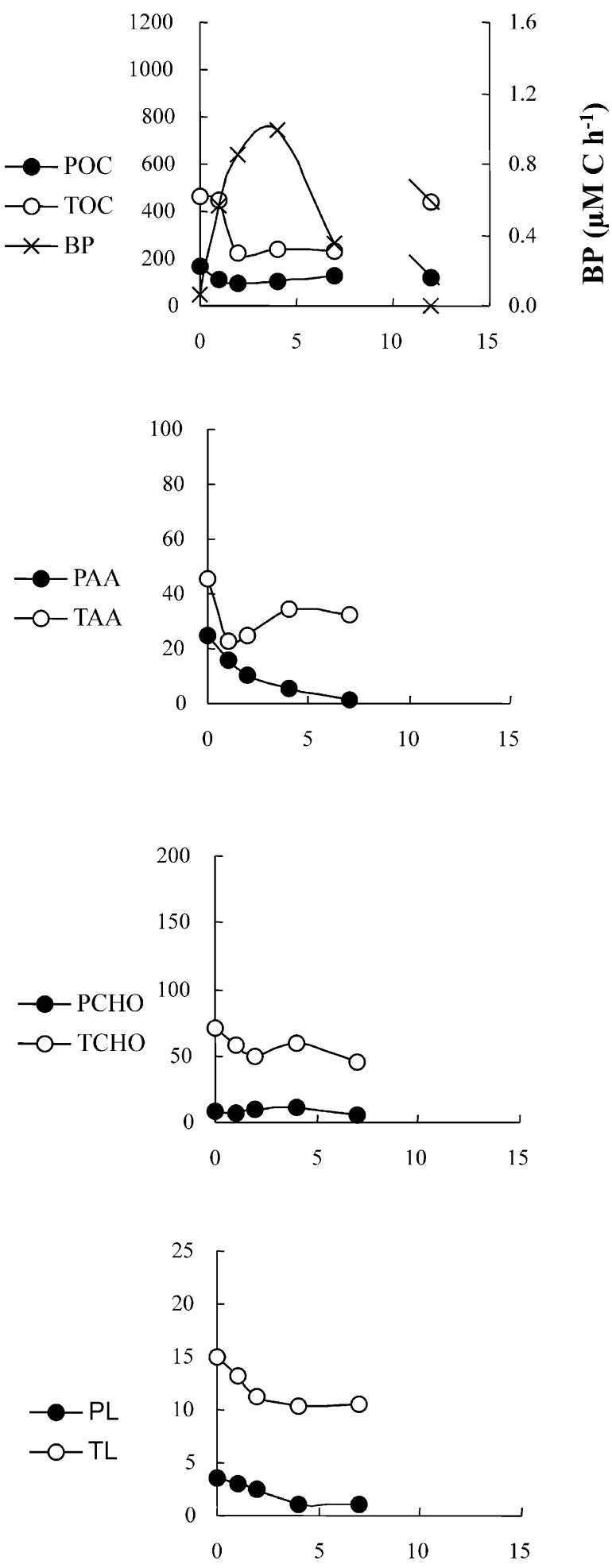

\section{Time (days)}

Fig. 3. Time course responses of particulate and total fractions of organic carbon, amino acids, sugars and lipids in relation to bacterial production during biodegradation experiments at SAr $30 \mathrm{~m}$ and $200 \mathrm{~m}$ depth. Same abbreviations as in Fig. 2. 


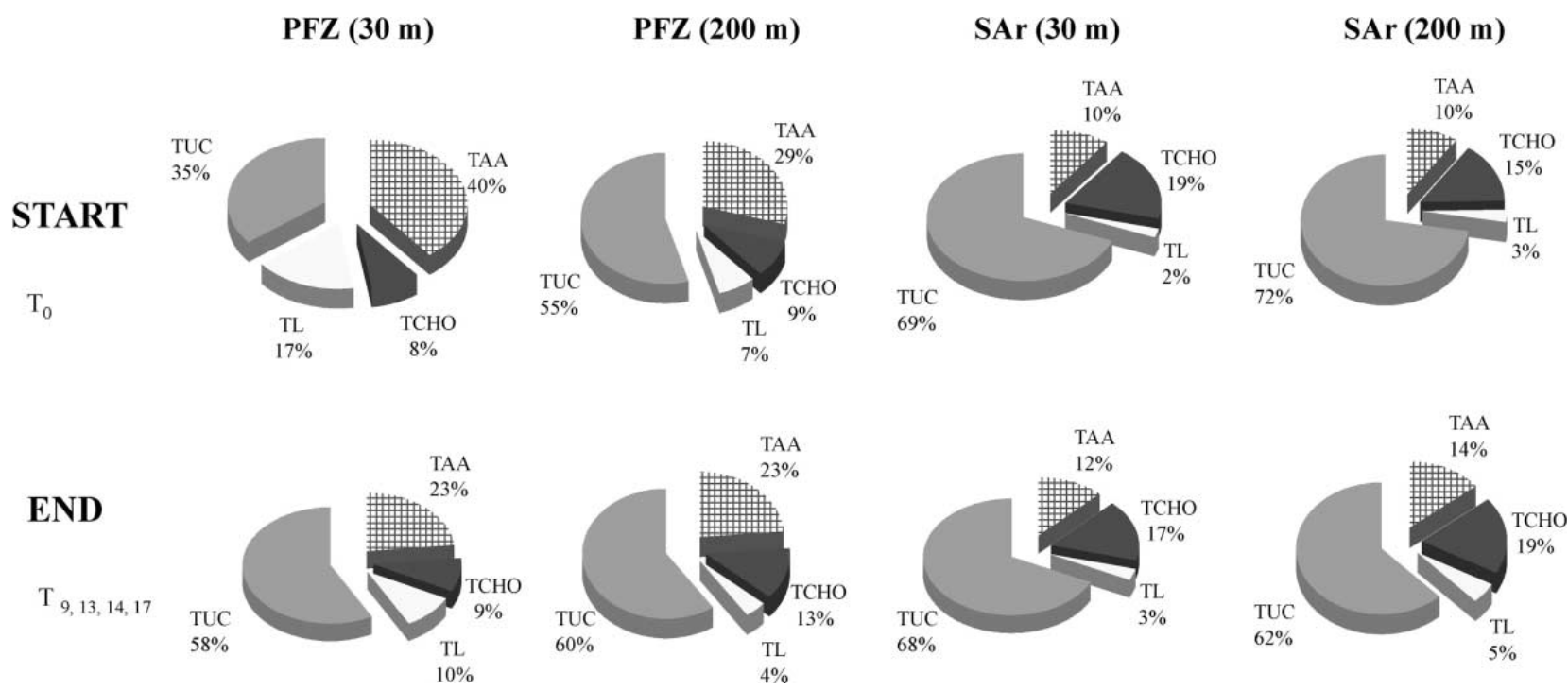

Fig. 4. Carbon contributions of characterized biochemicals to TOC at the beginning and end of the four biodegradation experiments. The fraction that could not be attributed to the amino acids, sugars and lipids is indicated as uncharacterized carbon (TUC). TUC was calculated as the difference between TOC and the sum in TAA-C + TCHO-C + TL-C.

\subsection{Amino acids, sugars and lipids concentrations during the experiment}

At the beginning of the incubation TAA comprised $29-40 \%$ of TOC $(200-30 \mathrm{~m})$ for PFZ-particles and $\sim 10 \%$ of TOC for SAr- particles indicating significant differences in the particle chemical composition between the two sites (Fig. 4). By the end of the time course experiment, TAA represented $23 \%$ and $12-14 \%$ of TOC for the PFZ- and SAr-particles, respectively (Fig. 4). At the PFZ, TAA concentrations decreased by $61 \%$ of their initial concentration at $30 \mathrm{~m}$ and by $54 \%$ at $200 \mathrm{~m}$ (Table 2). At SAr-particles, TAA concentrations decreased by only $\sim 30 \%$ of the initial concentration at both depths. Therefore, total amino acids compounds appeared to be largely degraded during the time course experiment.

At the beginning of the biodegradation experiments, TCHO comprised $8-9 \%$ and $15-19 \%$ of TOC of the particles $(200-30 \mathrm{~m})$ at $\mathrm{PFZ}$ and SAr, respectively (Fig. 4). By the end of the time course experiment, TCHO represented $9-13 \%$ and $17-19 \%$ of TOC of the PFZ and SAr-particles, respectively (at both depths, see Fig. 4). In PFZ-30 m experiment, TCHO concentrations decreased by $18 \%$ of their initial concentration at $30 \mathrm{~m}$ and $15 \%$ at $200 \mathrm{~m}$. In the SAr experiment, TCHO concentrations decreased by $37-50 \%$ of the initial concentrations (Table 2).

At $t=0$, TL comprised $7-17 \%$ and $2-3 \%$ of TOC of PFZ and SAr-particles, respectively (Fig. 4) indicating that the contribution of TL to TOC also varied between the two areas studied as did amino-acids and sugars. By the end of the experiment, TL represented $4-10 \%$ of TOC for PFZ and accounted 3-5\% of TOC for SAr- particles for both depths (Fig. 4), whilst TL concentrations decreased by $\sim 64 \%$ and by $14-30 \%$ of their initial concentrations for PFZ and SAr, respectively (Table 2).

\section{3. $B P$ and $B G E$}

In all samples, we observed an increase in BP during the first 2-7 days and a decrease thereafter until the end of the experiment (Figs. 2 and 3). The increase in BP was closely coupled with the decrease in TOC concentration. Our results showed that BP peaks observed at PFZ for both depths were rapidly reached within the first two days, whereas at Sar, maximum BP was reached after 4 days for both depths. BGE values were calculated for all samples at the end of the exponential growth of BP and ranged from 10 to $21 \%$, with slightly lower values for $30 \mathrm{~m}$ samples than $200 \mathrm{~m}$ samples for both stations (Table 2). The decline in BP after a few days at both sites and depths suggests that most of labile carbon was rapidly exhausted. Alternatively, the effect of nutrient exhaustion in the bottles or flagellate grazing on bacteria cannot be excluded (Newell et al., 1981; Harvey et al., 1995). Unfortunately, during incubation experiments we did not collect sample aliquots for further nutrient measurements. However, we believe that our incubation system was not nutrient limited because ambient nutrient concentrations are high (Leblanc et al., in press). On the other hand, as explained in materials and methods section, swimmers were discarded from filters. Additional information from epifluorescence microscopy did not show a significant number of heterotrophic flagellates at the beginning of the experiment, whereas only few of them were observed at the end the experiment and they were responsible for the bacterial biomass decrease (Figs. 2 and 3). 


\subsection{Degradation and mineralization rates of organic matter}

Organic matter degradation and mineralization rates $(k)$ were calculated for both fractions (particulate and total) for amino acids, sugars and lipids as well as for organic carbon according to the formula (Amon and Benner, 1996):

$k=\left(C_{\text {init }}-C_{\text {fin }}\right) \times(t)^{-1} \times\left(C_{\text {init }}\right)^{-1}$

where: $C_{\text {init }}$ is the initial concentration of any constituent, $C_{\text {fin }}$ is the final concentration of any constituent, $t$ is the incubation time.

All rates were normalized to the initial concentration at the incubation in order to provide a better measurement of the proportion of total or particulate fraction of each biochemical class that is readily available for bacterial consumption. Calculated values of $k$ for both stations and depths were: 0.022-0.072 $\mathrm{day}^{-1}$ for TOC, 0.021-0.047 day ${ }^{-1}$ for TAA, 0.003-0.053 $\mathrm{day}^{-1}$ for TCHO, 0.010-0.048 $\mathrm{day}^{-1}$ for TL (Table 3). A comparison between the different particulate pools revealed that PAA $\left(0.038-0.14 \mathrm{day}^{-1}\right)$ were the most rapidly degraded by bacteria followed by PL $\left(0.030-0.10\right.$ day $\left.^{-1}\right)$ and PCHO (0.016-0.049 day $\left.^{-1}\right)$.

It should be noted that the degradation rates of particulate material do not correlate with those of the total fractions because decomposition of particulate material produces dissolved compounds or submicronic particles $(<0.7 \mu \mathrm{m})$ which are not completely consumed by bacteria during the incubation time (Sempéré et al., 2000). Thus, mineralization rates of total organic pool (such as $k_{\mathrm{TOC}}$ ) are related to changes from organic to mineral state (i.e. $\mathrm{CO}_{2}$ ) while degradation rates of POM (such as $\left.k_{\mathrm{POC}}\right)$ are rather related to bacterial degradation as well as a transfer from particulate to dissolved state.

Table 3

Degradation (POC, PAA, PCHO, PL) and mineralization (TOC, TAA, TCHO, TL) rates determined in biodegradation experiments according to Eq. (2)

\begin{tabular}{llllll}
\hline Biochemical fraction & \multicolumn{2}{l}{$\mathrm{PFZ}$} & & \multicolumn{2}{l}{$\mathrm{SAr}$} \\
\cline { 2 - 3 } \cline { 6 - 6 } & $30 \mathrm{~m}$ & $200 \mathrm{~m}$ & & $30 \mathrm{~m}$ & $200 \mathrm{~m}$ \\
\hline$k_{\mathrm{TOC}}$ & 0.024 & 0.022 & & 0.030 & 0.072 \\
$k_{\mathrm{POC}}$ & 0.034 & 0.012 & & 0.017 & 0.031 \\
$\mathrm{k}_{\mathrm{TAA}}$ & 0.047 & 0.032 & & 0.021 & 0.041 \\
$k_{\mathrm{PAA}}$ & 0.073 & 0.038 & & 0.062 & 0.14 \\
$k_{\mathrm{TCHO}}$ & 0.014 & 0.003 & & 0.035 & 0.053 \\
$k_{\mathrm{PCHO}}$ & 0.016 & 0.018 & & 0.038 & 0.049 \\
$k_{\mathrm{TL}}$ & 0.048 & 0.037 & & 0.010 & 0.021 \\
$k_{\mathrm{PL}}$ & 0.050 & 0.034 & 0.030 & 0.10 \\
\hline
\end{tabular}

Units in $\mu \mathrm{mol} \mathrm{C} 1^{-1} \mathrm{day}^{-1} /\left(\mu \mathrm{mol} \mathrm{C}\right.$ init $\left.1^{-1}\right)$.

\section{Discussion}

\subsection{Mechanisms of particle decomposition}

Incubation of large particles showed a rapid response of bacteria to the input of labile organic material. Rapid breakdown of organic matter occurred during the first two days, after which rates slowed, presumably reflecting the degradation and mineralization of less labile compounds. Throughout the experimental period the labile fraction of consumed POC ( $\triangle \mathrm{POC}$; Table 2) was higher at $30 \mathrm{~m}(24-45 \%)$ than at $200 \mathrm{~m}(21-22 \%)$ at both sites, indicating that the organic matter of large particles at $200 \mathrm{~m}$ was more degraded than at $30 \mathrm{~m}$ at the time of sampling. Our results showed that DOC concentrations in the biodegradation experiments were much higher $(228-488 \mu \mathrm{MC})$ than those found in the water column (45-75 $\mu \mathrm{MC})$ indicating that sinking marine aggregates are potentially a source of DOC to the water column (Alldredge, 2000). These results are consistent with the paradigm that POC degradation is the result of ectoenzymatic activity of attached bacteria (Karner and Herndl, 1992; Smith et al., 1992) producing high $(>1 \mathrm{kDa})$ molecular weight dissolved organic compounds (Amon and Benner, 1996; Skoog and Benner, 1997). The latter are further enzymatically degraded to smaller molecules (500-1000 Da) that are partly transported across the bacterial membrane (Saier and Stiles, 1975; Hedges et al., 2000 and references therein).

A mean of $96 \%$ (range $78-109 \%$; Table 4 ) of the degraded POC fraction, was attributed to the degradation of characterizable compounds that constitute POC (sum of PAA, PCHO, PL). This percentage is much

Table 4

Net variations (in $\mu \mathrm{M} \mathrm{C}$ ) of the different pools of organic carbon $(\triangle \mathrm{TOC}, \triangle \mathrm{POC}, \triangle \mathrm{TAA}, \triangle \mathrm{PAA}, \triangle \mathrm{TCHO}, \triangle \mathrm{PCHO}$, $\Delta \mathrm{TL}, \Delta \mathrm{PL})$ calculated according to the formula: $\Delta=$ (final concentration-initial concentration)

\begin{tabular}{lccccc}
\hline & $\begin{array}{c}\Delta \mathrm{POC} \\
(\mu \mathrm{M} \mathrm{C})\end{array}$ & $\begin{array}{c}\Delta \mathrm{PAA} \\
(\mu \mathrm{M} \mathrm{C})\end{array}$ & $\begin{array}{c}\Delta \mathrm{PCHO} \\
(\mu \mathrm{M} \mathrm{C})\end{array}$ & $\begin{array}{c}\Delta \mathrm{PL} \\
(\mu \mathrm{M} \mathrm{C})\end{array}$ & $\begin{array}{r}\Delta \mathrm{PCC} / \\
\Delta \mathrm{POC}\end{array}$ \\
\hline PFZ 30 m & 437 & 324 & 9 & 143 & $109 \%$ \\
PFZ 200 m & 114 & 87 & 8 & 16 & $98 \%$ \\
SAr 30 m & 111 & 55 & 50 & 6 & $100 \%$ \\
SAr 200 m & 37 & 24 & 3 & 2 & $78 \%$ \\
& & & & & \\
& $\Delta$ TOC & $\Delta$ TAA & $\Delta$ TCHO & $\Delta \mathrm{TL}$ & $\Delta$ TCC/ \\
& $(\mu \mathrm{M} \mathrm{C})$ & $(\mu \mathrm{M} \mathrm{C})$ & $(\mu \mathrm{M} \mathrm{C})$ & $(\mu \mathrm{M} \mathrm{C})$ & $\Delta \mathrm{TOC}$ \\
& & & & & \\
PFZ 30 m & 474 & 332 & 19 & 146 & $105 \%$ \\
PFZ 200 m & 263 & 97 & 9 & 25 & $50 \%$ \\
SAr 30 m & 346 & 24 & 77 & 2 & $30 \%$ \\
SAr 200 m & 235 & 13 & 26 & 5 & $19 \%$ \\
\hline
\end{tabular}

$\triangle \mathrm{PCC}:$ is the sum of $\triangle \mathrm{PAA}+\triangle \mathrm{PCHO}+\Delta \mathrm{PL} . \triangle \mathrm{TCC}:$ is the sum of $\triangle \mathrm{TAA}+\Delta \mathrm{TCHO}+\Delta \mathrm{TL}$ 


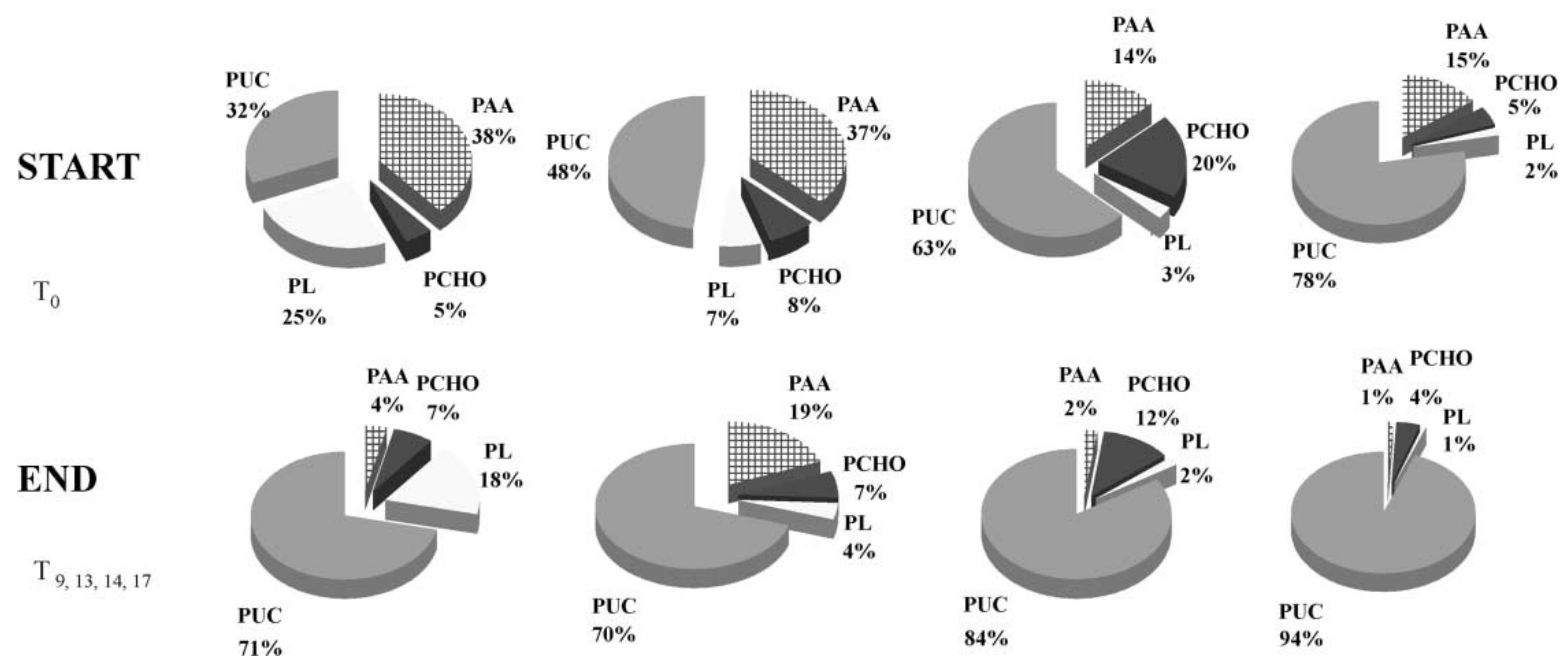

Fig. 5. Carbon contributions of characterized biochemicals to POC at the beginning and end of the four biodegradation experiments. The fraction that could not be attributed to the amino acids, sugars and lipids is indicated as uncharacterized carbon (PUC). PUC was calculated as the difference between POC and the sum in PAA-C + PCHO-C + PL-C.

higher than their initial contribution in POC (22-68\%; Fig. 5), indicating that attached bacteria preferentially degraded particulate characterizable compounds (PCC) in $>60 \mu \mathrm{m}$ particles. This is confirmed by the relatively high degradation rates for amino acids and lipids at both sites (Table 3 ) and the significant decreases of the $\%$ weight contributions of these pools to POC by the end of the experiment (Fig. 5). On the other hand, a preference for the PCC in the degraded POC fraction is not very evident when examining TOC mineralization. Indeed, only in PFZ $30 \mathrm{~m}$ experiment, bacteria preferentially mineralize the total characterizable compounds $(\triangle \mathrm{TCC} / \Delta \mathrm{TOC}=105 \%$; Table 4$)$, which is confirmed by the significant decrease of this characterized fraction (i.e. $\mathrm{TAA}+\mathrm{TCHO}+\mathrm{TL}$ ) by the end of the experiment (from 65 to $42 \%$; Fig. 4). In the other experiments, bacteria mineralized the TCC in more or less the same proportion as in the initial composition (SAr $30 \mathrm{~m}: \Delta \mathrm{TCC}$ / $\Delta \mathrm{TOC}=30 \%$ for a initial composition of $31 \%$; PFZ 200 $\mathrm{m}: \Delta \mathrm{TCC} / \Delta \mathrm{TOC}=50 \%$ for a initial composition of $45 \%$; SAr $200 \mathrm{~m}: \Delta \mathrm{TCC} / \Delta \mathrm{TOC}=19 \%$ for a initial composition of $28 \%$; Table 4, Fig. 4). Our results also showed that TCC contributed $\sim 38 \%$ (mean of the four experiments) of the TOC pool by the end of the experiments indicating that the composition of TOC becomes more uniform (Fig. 4). This is consistent with the findings of Wakeham et al. (1997b), who found that TCC contributed 24 and $20 \%$ to the organic carbon in deepwater particles and surface sediments, respectively.

\subsection{Efficiency of organic carbon utilization}

In the present study bacteria apparently turned over $32-38 \%$ and $43-50 \%$ of TOC in the PFZ and SAr biodegradation experiments within ca 14 days, mainly during exponential growth, indicating that mineralization of particles is more effective in SAr than in PFZ. The BGE values, calculated for the log growth phase, ranged from 10 to $21 \%$, resulting in high $\mathrm{CO}_{2}$ production, i.e. $79-90 \%$ of the assimilated carbon was respired by heterotrophic bacteria (Table 2). These BGE values are consistent with those reported for sinking particles in the water column (Smith et al., 1995: 9-17\%; Sempéré et al., 2000: 3-31\%) as well as for detrital aggregates incubated with deep-sea bacterial communities (Turley and Lochte, 1990: 5-80\%). A comparison of the two stations revealed similar BGE values, indicating that bacterial energy requirements may be similar despite different physical, biological and chemical processes at both sites (See study area; Rabouille et al., 1998; Leblanc et al., in press).

\subsection{Degradation and mineralization rates of organic matter}

Numerous studies of organic carbon decomposition have been undertaken for different matrices of organic matter, yielding rates ranging from less than a day to years. The wide range of values reported for POC degradation or TOC mineralization (Westrich and Berner, 1984; Turley and Lochte, 1990; Sun et al., 1993; Harvey et al., 1995; Harvey and Macko, 1997; Rabouille et al., 1998; Sempéré et al., 2000) might be due to the origin of particles or to different incubation times (i.e. longer incubation times yield slower rates), incubation temperatures, oxic or anoxic conditions, static or continual flow systems, as well as different applied models (first-order vs multi-G models or linear vs exponential 
models). For instance, Sempéré et al. (2000) found that mineralization rates of $>10 \mu \mathrm{m}$ Mediterranean particles were well fitted by a 2G-model. By applying Eq. (2) (Section 3.4) to the results of Sempéré et al. (2000) rates for the degradation of Mediterranean particles ranging from 0.021 to $0.041 \mathrm{day}^{-1}$ are determined, which are of the same order as those in the present study (Table 3). On the other hand, Harvey et al. (1995) and Harvey and Macko (1997), using a 1G-model, estimated degradation rates for individual chemical fractions (i.e. sugars, amino acids and lipids) during a phytoplankton decay. Their values ranged from 8.2 year $^{-1}\left(k_{\text {lipids }}\right)$ to 34.2 year $^{-1}\left(k_{\text {sugars }}\right)$ and were obtained for an incubation period of 45-77 days. However, if their results were calculated according to Eq. (2) (Section 3.4), they would range from 2.92 to 8.03 year $^{-1}$, again in the same order as the present study. Small differences between these results might be explained by the mathematical approach used for the calculations (i.e. linear-TOC decrease this study vs exponential-TOC decrease based on the model used by Harvey et al. (1995) and Harvey and Macko (1997). Varied incubation times (7-17 vs 4577 days) and nature of material may also contribute to the differences.

Mineralization rates of TOC in $200 \mathrm{~m}$ samples were higher in SAr than in PFZ waters, although the theoretical sinking fluxes at this depth were 0.43 and 0.57 mmol C m${ }^{-2}$ day $^{-1}$, respectively (Tables 1 and 3 ). We are aware a single result taken from experimental work where they may be significant errors, both experimental and analytical cannot be used to explain variations in the annual particle fluxes at these stations. However, these results indicate that organic carbon of sinking particles could be more rapidly remineralized in the SAr (depth $\sim 5000 \mathrm{~m}$ ) water column than in PFZ (depth $\sim 4000 \mathrm{~m}$ ), being consistent with the work of Rabouille et al. (1998) who showed higher POC flux deposited at the sediment-water interface in PFZ than in SAr.

The most striking feature of this kinetic study is that in PFZ, mineralization rates of amino acids and lipids associated with $>60 \mu \mathrm{m}$ particles were two to ten fold higher than sugars $\left(k_{\mathrm{TAA}}=0.032-0.047\right.$ day $^{-1}$; $k_{\mathrm{TL}}=0.037-0.048 \mathrm{day}^{-1}$ versus $k_{\mathrm{TCHO}}=0.003-0.014$ $\mathrm{day}^{-1}$ respectively; Table 3), whereas mineralization rates of sugars were higher than those of amino acids and lipids in $>60 \mu \mathrm{m}$ particles in SAr (Table 3). Moreover sugars were more efficiently consumed in SAr than in PFZ experiments (37 and 50\% of their initial amount versus 15 and $18 \%$, respectively; Table 2). Fig. 6 shows significant positive relationships between TL and TCHO in PFZ as well as TAA and TCHO in the time series samples from PFZ and SAr biodegradation experiments. Absence of correlation between TCHO and TL in SAr could not be explained in this study. Such relationship implies that bacteria utilized lipids, sugars and amino acids in the same proportion during the time course of the biodegradation experiment. Additionally, higher slopes of TL and TAA against TCHO confirms that in PFZ bacteria associated to $>60 \mu \mathrm{m}$ particles preferentially consumed lipids and amino acid rather than sugars. It is important to note that the initial composition of $>60 \mu \mathrm{m}$ particles in SAr was particularly carbohydrate rich and lean in other components such as lipids and amino acids (Fig. 4). Clearly these results indicate that the way that bacteria used the different fractions of particles was influenced by their initial chemical composition. On the other hand, our results showed that the PAA pool was more rapidly degraded $\left(0.038-0.14 \mathrm{day}^{-1}\right)$ than the PL $(0.030-0.10$ $\mathrm{day}^{-1}$ ) and PCHO (0.016-0.049 $\mathrm{day}^{-1}$ ) pools for all biodegradation experiments (Table 3 ). These results are consistent with the initial and final distribution of PAA in POC (Fig. 5) and indicate that dissolution processes from particulate to dissolved phase occurred more intensively with respect to amino acids rather than sugars and lipids, suggesting higher ectoenzymatic activities of proteins compared to those of sugars and lipids (Smith et al., 1992).

\subsection{Chemical composition of $>60 \mu \mathrm{m}$ particles}

Recent studies indicated that sugars, amino acids and lipids accounted for $80 \%$ of the organic carbon in particles exported from the euphotic zone (Wakeham et al., 1997b), with the highest contribution by amino acids (Lee et al., 2000, 60\%) followed by lipids (Wakeham et al., 1997a, 15\%) and carbohydrates (Hernes et al., 1996, $5 \%$ ). In the present study, these components accounted only $28-65 \%$ of organic carbon (see initial composition of TOC, Fig. 4). One possible explanation is that in situ pumps collect a wide spectrum of particle sizes including large and small (and already degraded) particles, whereas sediment traps, which were used in previous studies collect only fast large sinking particles (that are probably less degraded). Alternatively, these results may be due to natural variability or to the assumptions made for the carbon conversion factors. Our results also showed that the total uncharacterized carbon (TUC) fraction was higher at $200 \mathrm{~m}(55 \% \mathrm{PFZ} ; 72 \% \mathrm{SAr})$ than at $30 \mathrm{~m} \mathrm{(35 \%} \mathrm{PFZ;} 69 \% \mathrm{SAr})$, which is in agreement with previous investigations (Wakeham et al., 1997b; Hedges et al., 2000).

The initial chemical composition of $>60 \mu \mathrm{m}$ particles varied markedly between the two sites. Our results indicated that the fraction of TOC that could be attributed to the main characterized biochemical classes (amino acids, lipids and sugars) was higher in the PFZ-particles $(65 \%$ at $30 \mathrm{~m}$ and $45 \%$ at $200 \mathrm{~m})$ than in the SAr-particles $(31 \%$ at $30 \mathrm{~m}$ and $28 \%$ at $200 \mathrm{~m}$ ) (Fig. 4). Amino acids were predominant $(200 \mathrm{~m})$ or relatively abundant $(30 \mathrm{~m})$ in PFZ-particles $(29-40 \%$ of TOC), whereas carbohydrates were relatively more abundant in SAr 


\section{○ PFZ $\triangle$ SAr}
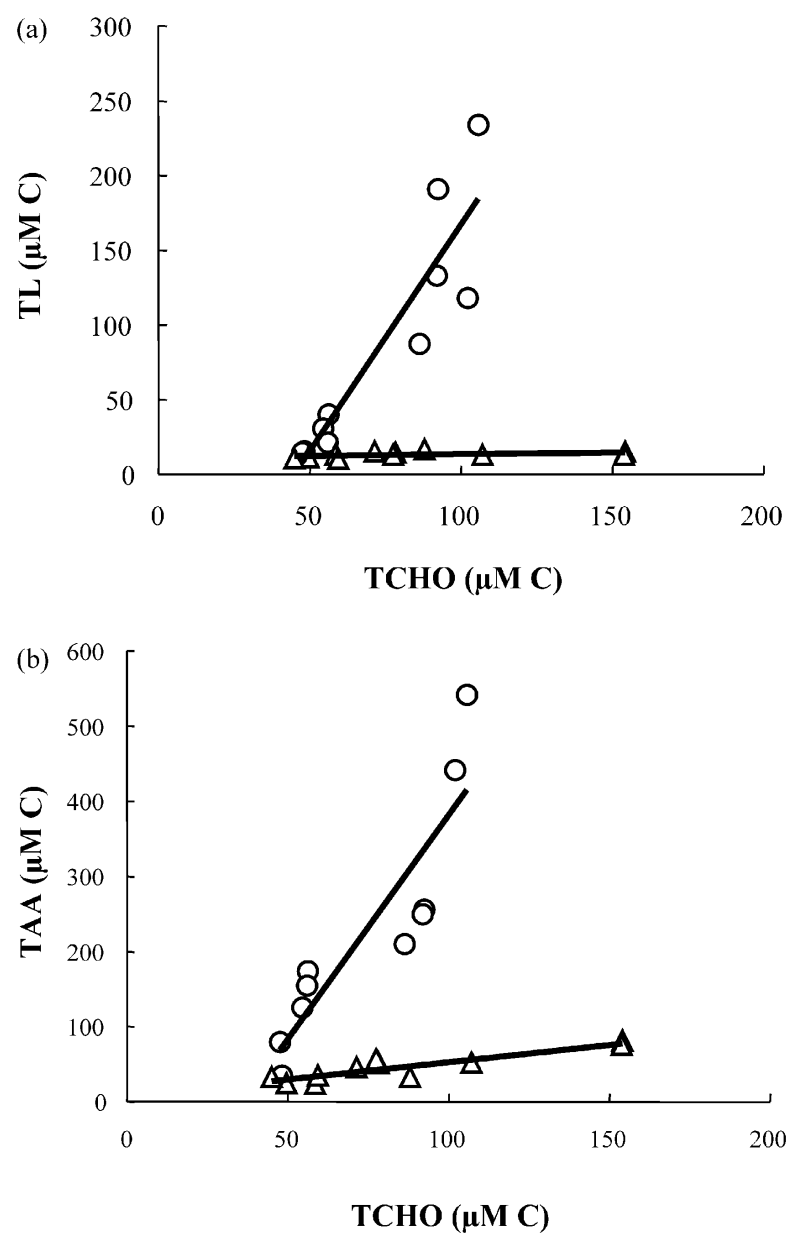

Fig. 6. Concentrations ( $\mu \mathrm{M} \mathrm{C})$ of total lipids (a) and amino acids (b) versus total sugars in the time series samples during biodegradation experiments performed in PFZ and SAr. For each regression line from 30 and $200 \mathrm{~m}$ experimental data are pooled. Each regression line is described as follows: PFZ: $\mathrm{TL}=3 \times \mathrm{TCHO}-136 ; \quad r=0.91 ; \quad P<0.001 ; \quad n=10 ; \quad \mathrm{SAr}:$ $\mathrm{TL}=0.02 \times \mathrm{TCHO}+11 ; \quad r=0.43 ; \quad P>0.05 ; \quad n=11 ; \quad$ PFZ: $\mathrm{TAA}=5.97 \times \mathrm{TCHO}-216 ; \quad r=0.89 ; \quad P<0.001 ; \quad n=10 ; \quad \mathrm{SAr}:$ $\mathrm{TAA}=0.46 \times \mathrm{TCHO}+7.06 ; r=0.90 ; P<0.001 ; n=11$.

surface waters (15-19\% of TOC). Since amino acids are typical of fresh algal detritus and are more rapidly degraded than other biochemical classes (Harvey et al., 1995; Harvey and Mannino, 2001) their high relative abundance in PFZ suggests that particles were initially less degraded in PFZ waters than in the SAr waters.

Alternatively, different planktonic populations might explain variations in the chemical composition as indicated above. Biological observations indicated that diatoms (partly dissolved) as well as dinoflagellates were relatively more abundant (particularly Pseudo Nitszschia sp.) in SAr, which is confirmed by particulate lipid analyses (data not shown) whereas PFZ was characterized by an important accumulation of coccoliths of Michaelsaisia sp. (Leblanc et al., in press).

Other investigations reported higher potential dissolution rates of biogenic silica (Leblanc et al., in press) and higher BP in surface waters $(0-150 \mathrm{~m})$ of the SAr compared to the cold waters of the PFZ (unpublished observations). It is well known that organic matter decomposition is related to silica dissolution (Lewin, 1961; Bidle and Azam, 1999), which is controlled by temperature (Nelson et al., 1995) as well as by bacterial activity (Bidle and Azam, 1999). Therefore, we suggest that $>60 \mu \mathrm{m}$ particles in SAr are depleted in amino acids and lipids because they were more degraded at the time of collection, due to the high dissolution rate of the silica frustules as well as the higher BP and temperature, encountered in these waters (Table 1). Conversely, colder temperatures and lower bacterial activity in the PFZ probably prevent extensive dissolution of dead diatoms and subsequent amino-acid and lipid consumption by bacteria. This is in consistent with other investigations indicating that PFZ waters are particularly enriched in biogenic silica compared to POC (Leblanc et al., in press). The higher abundance of carbohydrates in $>60 \mu \mathrm{m}$ particles in SAr waters could derive from different macromolecular material that is resistant to bacterial degradation, but is measurable by conventional analysis (Hedges et al., 2001). Refractory organic or inorganic matrices may shield intrinsically labile organic substances (Knicker et al., 1996) which may then persist much longer than other organic compounds, such as proteins and lipids.

\section{Conclusions}

The main results concerning $>60 \mu \mathrm{m}$ particles degradation in the two sites examined (PFZ, SAr) in the southern Indian Ocean obtained by bulk analysis of POC, DOC, amino acids, sugars and lipids as well as bacterial production measurements are summarized below:

- Bacteria preferentially degraded PCC $(\mathrm{PCC}=\mathrm{PAA}+\mathrm{PCHO}+\mathrm{PL})$ in a high percentage $(96 \%)$.

- By the end of the experiment, the composition of particles became uniform and the sum of biochemicals analyzed (sugars, amino acids and lipids) contributed $\sim 36 \%$ of the TOC pool.

- During the experiments, $32-38 \%$ and $43-50 \%$ of TOC were mineralized and considered as labile material in the PFZ and SAr, respectively. This material was utilized with a bacterial 
growth efficiency (BGE) of 10-21\% (PFZ) and $12-17 \%$ (SAr), indicating that $79-90 \%$ of the incorporated carbon from large particles was respired as $\mathrm{CO}_{2}$.

- This study revealed that the initial relative abundance of the three main classes of organic matter, including amino acids, lipids and sugars, greatly varied between SAr and PFZ, with sugars being more abundant in SAr-particles (15-19\% of TOC) than in PFZ-particles (8-9\% of TOC). Additionally, a kinetic model indicated that in PFZ mineralization rates of amino acids and lipids were two to ten fold higher than those of sugars, whereas the opposite was the case in the SAr biodegradation experiments. These results strongly suggest that bacterial decomposition of organic matter is influenced by its initial chemical composition.

- The differences observed in initial particle composition and mineralization rates between the two sites (PFZ and SAr) may be best explained by the higher dissolution processes of silica as well as by higher temperatures and $\mathrm{BP}$ in $\mathrm{SAr}$ waters.

These observations suggest that both processes (different origin of particles and selective biodegradation) may act together and affect the composition of sinking material to the ocean interior. Our study suggests that bacteria rapidly mineralized a higher proportion of sinking particles leaving the euphotic layer in SAr rather than in PFZ waters. Therefore it is not surprising that there is little material reaching the sea-floor in SAr compared to PFZ (Rabouille et al., 1998). The coupling of colder temperatures, high biogenic silica and lower mineralization rates at PFZ, probably can facilitate the $>60 \mu \mathrm{m}$ particles to reach the sea-floor in this region.

\section{Acknowledgements}

We are grateful to A. Bianchi, R. Fukuda, K. Leblanc, K. Mopper and D. Delmas and two anonymous reviewers for comments on the manuscript and fruitful discussions. Our thanks to the captain and crew of Marion Dufresne for excellent service at sea as well as to Jacques Le Fèvre (leader of the Antares project) and M. Denis (chief scientist of Antares-4 oceanographic cruise). We also thank Catherine Jeandel, Claudie Bournot-Marec, and Laurent Coppola for help with particle collection and batch preparations during the cruise. This research was supported by France-PROOF Antares-4 project. Financial support for C.P. came from the Alexander S. Onassis Public Benefit Foundation, Greece.

\section{References}

Arraes-Mescoff, R., Roy-Barman, M., Coppola, L., Souhaut, M., Tachikawa, K., Jeandel, C., Sempéré, R., Yoro, C., 2001. The behavior of $\mathrm{Al}, \mathrm{Mn}, \mathrm{Ba}, \mathrm{Sr}, \mathrm{REE}$ and Th isotopes during in vitro degradation of large marine particles. Marine Chemistry $73,1-19$.

Alldredge, A.L., Silver, M.W., 1988. Characteristics, dynamics and significance of marine snow. Progress in Oceanography 20, 41-82.

Alldredge, A.L., Passow, U., Logan, B.E., 1993. The abundance and significance of a class of large, transparent organic particles in the ocean. Deep-Sea Research I 40, 1131-1140.

Alldredge, A.L., 2000. Interstitial dissolved organic carbon (DOC) concentrations within sinking marine aggregates and their potential contribution to carbon flux. Limnology and Oceanography 45, 1245-1253.

Asper, V.L., Deuser, W.G., Knauer, G.A., Lohrenz, S.E., 1992. Rapid coupling of sinking particle fluxes between surface and deep ocean waters. Nature 357, 670-672.

Amon, R.M.W., Benner, R., 1996. Bacterial utilization of different classes of dissolved organic matter. Limnology and Oceanography 41, 41-51.

Berner, R., 1980. Early Diagenesis: A Theoretical Approach. Princeton University Press, Princeton.

Bidle, K.D., Azam, F., 1999. Accelerated dissolution of diatom silica by marine bacterial assemblages. Nature 397, 508-512.

Bligh, E.G., Dyer, W.J., 1959. A rapid method of total lipid extraction and purification. Canadian Journal of Biochemical Physiology 37, 911-917.

Burney, C.M., Sieburth, J.McN., 1977. Dissolved carbohydrates in seawater. II, A spectrophotometric procedure for total carbohydrate analysis and polysaccharide estimation. Marine Chemistry 5, 15-28.

Cailliau, C., Belviso, S., Goutx, M., Bedo, A., Park, Y., Charriaud, E., 1999. Sedimentation pathways in the indian sector of the Southern Ocean during a production regime dominated by regeneration. Marine Ecology Progress Series 190, 53-67.

Cho, B.C., Azam, F., 1988. Major role of bacteria in biogeochemical fluxes in the ocean's interior. Nature 332, 441-443.

Dafner, E.V., Sempéré, R., Bryden, H.L., 2001. Total organic carbon distribution and budget through the Strait of Gibraltar in April 1998. Marine Chemistry 73, 233-252.

de Baar, H.J.W., de Jong, J.T.M., Bakker, D.C.E., Löscher, B.M., Veth, C., Bathman, U., Smetacek, V., 1995. Importance of iron for plankton blooms and carbon dioxide drawdown in the Southern Ocean. Nature 373, 412-415.

Delmas, D., Frikha, M.G., Linley, E.A.S., 1990. Dissolved primary amine measurement by flow injection analysis with $o$-pthaldialdeyde: comparison with high-performance liquid chromatography. Marine Chemistry 29, 145-154.

Fowler, S., Knauer, G., 1986. Role of large particles in the transport of elements and organic compounds through the oceanic water column. Progress in Oceanography 16, 47-194. 
Goutx, M., Momzikoff, A., Striby, L., Andersen, V., Marty, J.C., Vescovali, I., 2000. High-frequency of labile compounds in the central Ligurian Sea, northwestern Mediterranean. Deep-Sea Research I 47, 533-556.

Harvey, H.R., Tuttle, J., Bell, J., 1995. Kinetics of phytoplankton decay during simulated sedimentation: changes in biochemical composition and microbial activity under oxic and anoxic conditions. Geochimica et Cosmochimica Acta 59, 3367-3377.

Harvey, H.R., Macko, S.A., 1997. Kinetics of phytoplankton decay during simulated sedimentation: changes in lipids under oxic and anoxic conditions. Organic Geochemistry 27, 129-140.

Harvey, H.R., Mannino, A., 2001. The chemical composition and cycling of particulate and macromolecular dissolved organic matter in temperate estuaries as revealed by molecular organic tracers. Organic Geochemistry 32, 527-542.

Hedges, J.I., Eglinton, G., Hatcher, P.G., Kirchman, D.L., Arnosti, C., Derenne, S., Evershed, R.P., Kögel-Knabner, I., de Leeuw, J.W., Littke, R., Michaelis, W., Rullköter, J., 2000. The molecularly-uncharacterized component of nonliving organic matter in natural environments. Organic Geochemistry $31,945-958$.

Hedges, J.I., Baldock, J.A., Gélinas, Y., Lee, C., Peterson, M., Wakeham, S.G., 2001. Evidence for non-selective preservation of organic matter in sinking marine particles. Nature 409, 801-804.

Herndl, G.J., 1988. Ecology of amorphous aggregations (marine snow) in the northern Adriatic Sea: II. Microbial density and activity in marine snow and its implication to overall pelagic processes. Marine Ecology Progress Series 48, 265 275 .

Hernes, P.J., Hedges, J.I., Peterson, M.L., Wakeham, S.G., Lee, C., 1996. Neutral carbohydrate geochemistry of particulate material in the central equatorial Pacific. Deep-Sea Research II 43, 1181-1204.

Henrichs, S., Doyle, A., 1986. Decomposition of ${ }^{14} \mathrm{C}$ labeled organic substances in marine sediments. Limnology and Oceanography $31,765-778$.

Hoppe, H.G., Ducklow, H., Karrash, B., 1993. Evidence for dependency of bacterial growth on enzymatic hydrolysis of particulate organic matter in the mesopelagic ocean. Marine Ecology Progress Series 93, 277-283.

Ittekkot, V., Deuser, W.G., Degens, E.T., 1984. Seasonality in the fluxes of sugars, amino acids, and amino sugars to the deep ocean: Sargasso Sea. Deep-Sea Research 31, 10571069.

Karner, M., Herndl, G.J., 1992. Extracellular enzymatic activity and secondary production in free-living and marine-snowassociated bacteria. Marine Biology 113, 341-347.

Kirchman, D.L., 1993. Leucine incoporation as a measure of biomass production by heterotrophic bacteria. In: Kemp, P.F., Sherr, B.F., Sherr, E.B., Cole, J.J. (Eds.), Handbook of Methods in Aquatic Microbial Ecology. Lewis publishers, Ann Arbor, pp. 509-512.

Kiriakoulakis, K., Stutt, E., Rowland, S.J., Vangriesheim, A., Lampitt, R.S., Wolff, G.A., 2001. Controls on the organic chemical composition of settling particles in the Northeast Atlantic ocean. Progress in Oceanography 50, 65-87.

Knicker, H., Scaroni, A.W., Hatcher, P.G., 1996. ${ }^{13} \mathrm{C}$ and ${ }^{15} \mathrm{~N}$ NMR spectroscopy investigation on the formation of fossil algal residues. Organic Geochemistry 24, 661-669.
Leblanc, K., Queguiner, B., Fiala, M., Blain, S., Morvan, J., Corvaisier, R. Particulate biogenic silica and carbon production rates and particulate matter distribution in the Indian sector of the Subantarctic Ocean. Special Issue SOJGOFS, Vol 2, Deep Sea Research II (in press).

Lee, C., Cronin, C., 1982. The vertical flux of particulate organic nitrogen in the sea: decomposition of amino acids in the Peru upwelling area and the equatorial Atlantic. Journal of Marine Research 40, 227-251.

Lee, C., Wakeham, S.G., Hedges, J.I., 2000. Composition and flux of particulate amino acids and chloropigments in equatorial Pacific seawater and sediments. Deep-Sea Research I 47, 1535-1568.

Lewin, J.C., 1961. The dissolution of silica from diatoms walls. Geochimica and Geophysical Acta 21, 182-198.

Martin, J.H., Knauer, D.M., Karl, D.M., Broenkow, W.W., 1987. VERTEX: carbon cycling in the northeast Pacific. Deep-Sea Research 34, 267-285.

Metzl, N., Tilbrook, B., Poisson, A., 1999. The annual $\mathrm{fCO}_{2}$ cycle and the air-sea $\mathrm{CO}_{2}$ flux in the sub-Antarctic Ocean. Tellus 4, 177-196.

Mopper, K., Schultz, C., Chevolot, L., Germain, C., Revuelta, R., Dawson, R., 1992. Determination of sugars in unconcentrated seawater and other natural waters by liquid chromatography. Environmental Science and Technology 26, 133-137.

Myklestad, S.V., Skånøy, E., Hestmann, S., 1997. A sensitive method for analysis of dissolved mono- and polysaccharides in seawater. Marine Chemistry 56, 279-286.

Nelson, D.M., Tréguer, P., Brzezinski, M.A., Leynaert, A., Queguiner, B., 1995. Production and dissolution of biogenic silica in the ocean: revised global estimates, comparison with regional data and relationship to biogenic sedimentation. Global Biochemical Cycles 9, 359-372.

Newell, R., Lucas, M.I., Linley, E.A.S., 1981. Rate of degradation and efficiency of conversion of phytoplankton debris by marine micro-organisms. Marine Ecology Progress Series 6, 123-136.

Nguyen, R., Harvey, H., 1997. Protein and amino acid cycling during phytoplankton decomposition in oxic and anoxic waters. Organic Geochemistry 27, 115-128.

Ogawa, H., Ogura, N., 1992. Comparison of two methods for measuring dissolved organic carbon in seawater. Nature 356, 696-698.

Panagiotopoulos, C., Sempéré, R., Lafont, R., Kerhervé, P., 2001. Sub-ambient temperature effects on separation of monosaccharides by HPAEC-PAD. Application to marine chemistry. Journal of chromatography A 920, 13-22.

Park, Y.H., Gamberoni, L., 1997. Cross-frontal exchange of Antarctic Intermediate water and antarctic bottom water in the Crozet Basin. Deep-Sea Research 44, 963-986.

Parsons, T.R., Maita, Y., Lalli, C.M., 1984. A Manual of Chemical and Biological Methods for Seawater Analysis. Pergamon, Oxford. pp. 44-55.

Rabouille, C., Gaillard, J.F., Relexans, J.C., Treguer, P., Vincendeau, M.A., 1998. Recycling of organic matter in Antarctic sediments: a transect through the polar front in the southern Ocean (Indian Sector). Limnology Oceanography 43, 420-432.

Saier, M., Stiles, C.D., 1975. Molecular Dynamics in Biological Membranes. Heidelberg Science Library 22. Springer, Berlin.

Sempéré, R., Yoro, S.C., Van Wambeke, F., Charrière, B., 2000. Microbial decomposition of large organic particles in 
the Northwestern Mediterranean Sea: an experimental approach. Marine Ecology Progress Series 198, 61-72.

Sempéré, R., Panagiotopoulos, C., Lafont, R., Marroni, B., Van Wambeke, F., 2002. Total organic carbon dynamics in the Aegean Sea. Journal of Marine Systems 33-34, 355-364.

Siegenthaler, U., Sarmiento, J.L., 1993. Atmospheric carbon dioxide and the ocean. Nature 365, 119-125.

Skoog, A., Benner, R., 1997. Aldoses in various size fractions of marine organic matter: implications for carbon cycling. Limnology and Oceanography 42, 1803-1813.

Smith, D.C., Simon, M., Alldredge, A., Azam, F., 1992. Intense hydrolytic enzyme activity on marine aggregates and implications for rapid particles dissolution. Nature 359, 139 142.

Smith, D.C., Steward, G.F., Long, R.A., Azam, F., 1995. Bacterial mediation of carbon fluxes during a diatom bloom in a mesocosm. Deep-Sea Research II 42, 75-97.

Striby, L., Lafont, R., Goutx, M., 1999. Improvement in the Iatroscan thin-layer chromatographic-flame ionization detection analysis of marine lipids. Separation and quantitation of monoacylglycerols and diacylglycerols in standards and natural samples. Journal of Chromatography A 849, 371-380.

Sun, M.Y., Lee, C., Aller, R.C., 1993. Laboratory studies of oxic and anoxic degradation of chlorophyll- $\alpha$ in Long Island Sound sediments. Geochimica et Cosmochimica Acta 57, 147-157.

Tan, F.C., Strain, P.M., 1979. Carbon isotope ratios of particulate organic matter in the Gulf of St. Lawrence. Journal Fish Research Board Can 36, 678-682.
Tanoue, E., Handa, N., 1987. Monosaccharide composition of marine particles and sediments from the Bering Sea and nothern North Pacific. Oceanologica Acta 10, 91-99.

Turley, C., Lochte, K., 1990. Microbial response to the input of fresh detritus to the deep-sea bed. Palaeogeography, Palaeoclimatology, Palaeoecology (Global and Planetary Change Section) 89, 3-23.

Van Wambeke, F., Goutx, M., Striby, L., Sempéré, R., Vidussi, F., 2001. Bacterial dynamics during the transition from spring bloom to oligotrophy in the northwestern Mediterranean Sea: relationships with particulate detritus and dissolved organic matter. Marine Ecology Progress Series 212, 89-105.

Wakeham, S.G., Lee, C., Farrington, J.W., Gagosian, R., 1984. Biogeochemistry of particulate organic matter in the ocean: results from sediment trap experiments. Deep Sea Research 31, 509-528.

Wakeham, S.G., Hedges, J.I., Lee, C., Peterson, M.L., Hernes, P.J., 1997a. Compositions and transport of lipid biomarkers through the water column and surficial sediments of the equatorial Pacific Ocean. Deep-Sea Research II 44, 2131-2162.

Wakeham, S.G., Lee, C., Hedges, J.I., Hernes, P.J., Peterson, M.L., 1997b. Molecular indicators of diagenetic status in marine organic matter. Geochimica et Cosmochimica Acta $61,5363-5369$.

Westrich, J., Berner, R., 1984. The role of sedimentary organic matter in bacterial sulphate reduction: the $\mathrm{G}$ model tested. Limnology and Oceanography 29, 236-249.

Yoro, S.C., Panagiotopoulos, C., Sempéré, R., 1999. Dissolved organic carbon contamination induced by filters and storage bottles. Water Research 33, 1956-1959. 